\title{
Adoption of Technology-Based Product by Consumers: A Review
}

\author{
Santanu K. Satapathy \\ National Institute Of Industrial Engineering (NITIE) \\ Vihar Lake Road, Powai, Mumbai, 400 087, Maharastra, India \\ E-mail: Santanu.Satapathy1@Gmail.Com \\ Shirish Sangle \\ National Institute Of Industrial Engineering (NITIE) \\ Vihar Lake Road, Powai, Mumbai, 400 087, Maharastra, India \\ E-mail: Sangle.Shirish@Gmail.Com \\ Seema Unnikrishnan \\ National Institute Of Industrial Engineering (NITIE) \\ Vihar Lake Road, Powai, Mumbai, 400 087, Maharastra, India \\ E-mail: Seemaunnikrishnan@Gmail.Com
}

Received: April 17, 2016

doi:10.5296/emsd.v5i2.9329
Accepted: May 4, 2016

URL: http://dx.doi.org/10.5296/emsd.v5i2.9329

\begin{abstract}
Technology-Based Product (TBP) Adoption By The Consumers Is Now Widely Acknowledged As A Key Aspect Of Sustainable Consumption. TBP Has Been Studied By Several Researchers To Identify The Key Variables Of Its Adoption. This Article Describes The Analysis Of Selective Papers, Explaining Various Factors Affecting The Adoption Of TBP By The Consumers. A Few Models Proposed By Researchers Are Discussed For A Better Understanding Of The Consumer Behavior As Well As The Variables For TBP Adoption. This Review Paper Also Gives A Comprehensive List Of
\end{abstract}


Findings In The Area Of TBP Adoption. While Focusing On The Research Conducted In The Past, The Review Paper Emphasizes The Need For More Empirical Studies In The Area. The Article Brings Out The Research Gaps Pertaining To The Establishment Of The Relation Between Adoption Of TBP And Climate Change. The Paper Concludes With The Discussion Of Further Research Needed In The Area Of TBP Adoption In India.

Keywords: Technology-Based Product, Sustainable Consumption, Climate Change, India, Consumers

\section{Introduction}

New products and services are offered to the customers every day, and companies around the world are competing with each other in order to increase their market share (Ansari and Riasi, 2016). However, many companies in the market are not environmentally friendly and do not adhere to international standards (Raisi and Amiri Aghdaie, 2013). Purchase and consumption decisions are an integral part of human life. Every purchase decision and consumption has some amount of Greenhouse Gas (GHG) emission that consequently, contributes to the global climate change (Shourmatoff, 2007).

Human consumption habits are one of the key factors contributing to the climate problem. The price paid is primarily for the goods and services consumed, but the price for GHG emissions and its impact remains hidden and is not paid by the consumers. This demonstrates that consumers' attention is focused on the attributes of the products, and rare consideration is given towards the adverse effects associated with the products. Considering both the desired and undesired attributes of the products during its purchase is a challenge for each and every individual (KSG Working Paper, 2003).

This review paper intends to collate the studies conducted on the adoption of Technology-Based Products. First, the literature review has been carried out, followed by a discussion on the specific frameworks proposed by the researchers. The review finally summarizes the previous research findings and proposes future research areas.

\section{Method Used For Literature Survey}

\subsection{Literature Search}

The concept of sustainable consumption and focusing on cleaner technology development has been accepted as the ultimate goal for all the nations and people to deal with environmental degradation and combat the global climate change (Rio de Janeiro in 1992).

This literature review has covered research studies from 1990 to 2016. Also, key articles from the cross references of main articles are included in the review, though these have not been published during the review period. There are three key focus areas in this review paper. The first focus area summarizes the studies conducted on TBP adoption. Second focus area correlates the studies on TBP adoption with climate change. The third focus area of this review paper sums up the research models on TBP adoption. The future research needs regarding TBP adoption, particularly for Indian consumers, have also been stressed in this 


\section{Macrothink}

article.

\subsection{Article Selection}

Different keywords were used to select research articles related to TBP Adoption. These were, 'Technology-Based Product,' 'household appliances,' 'white goods,' 'electronic appliances,' 'consumer behavior,' 'sustainable consumption,' and 'individual GHG emission.' Google Trend was used to find out the global and Indian search trends for two related terms. The peak in global search traffic for the term *sustainable consumption* was found between 2006 and 2007, and the gradual decrease was seen till 2015 (Figure 1). A similar peak was also observed during 2004 in a developing country like India, but sudden fall in search for the term *sustainable consumption* was observed after 2011. Also, there were zero searches observed during recent days (Figure 3).

Similarly, the peak in global search traffic for the term *electrical appliances* was around end of 2004, with the number of searches being nearly constant since 2007 (Figure 2). For a developing country like India, the search for *electrical appliances* peaked during 2004 and 2005. Gradual fall was observed in the figure from 2007 to 2011, and a very low trend has been continuing after 2011 (Figure 4). All the following four trends were prepared through https://www.google.co.in/trends/.

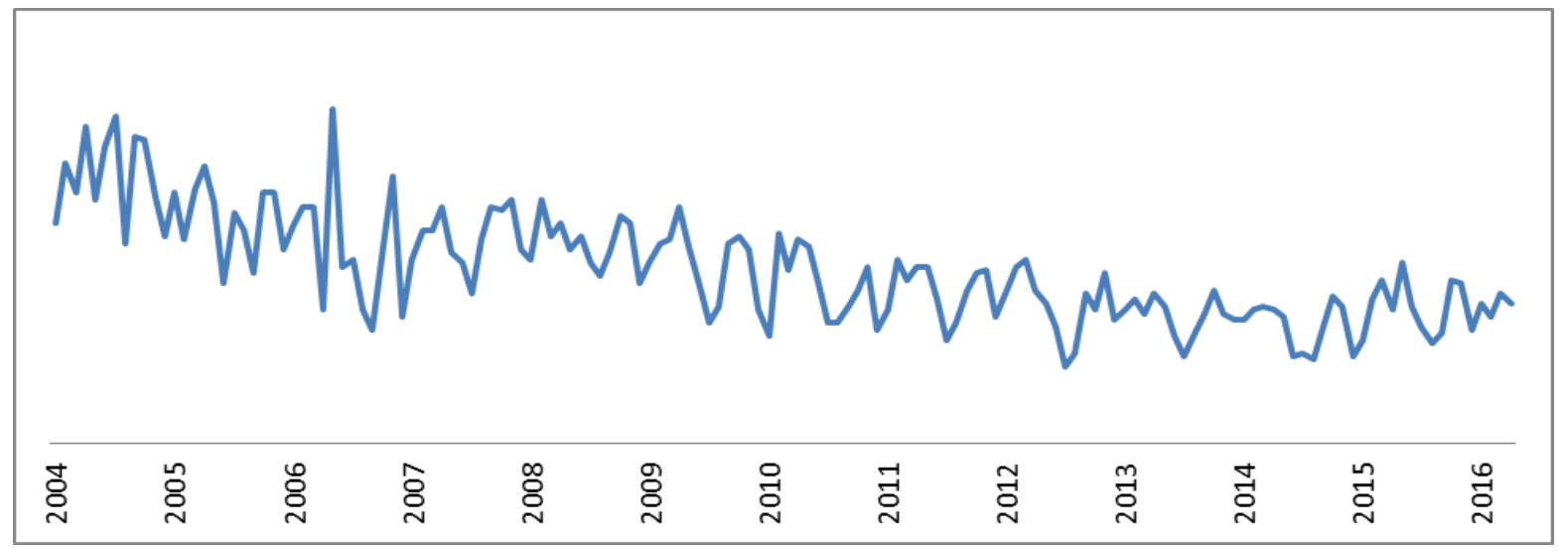

Figure 1. ‘Sustainable Consumption’ Worldwide Search Trend

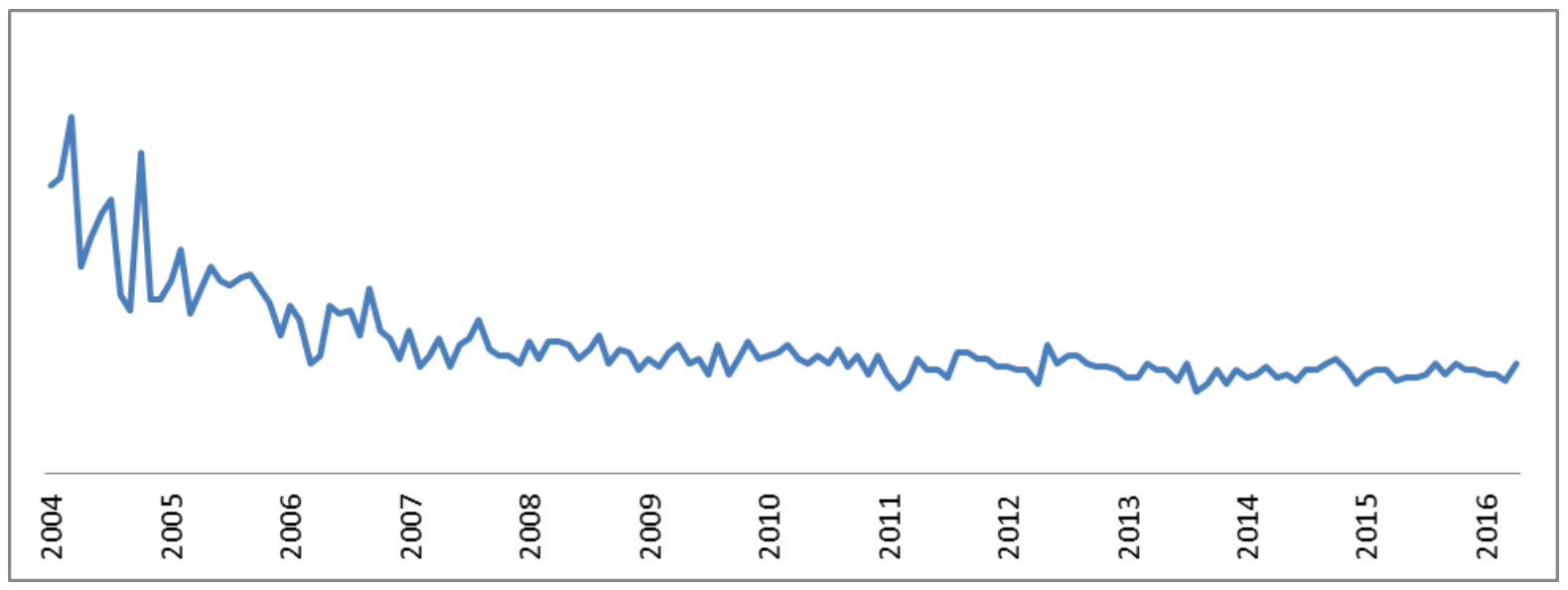

Figure 2. 'Electronic Appliances’ Worldwide Search Trend 


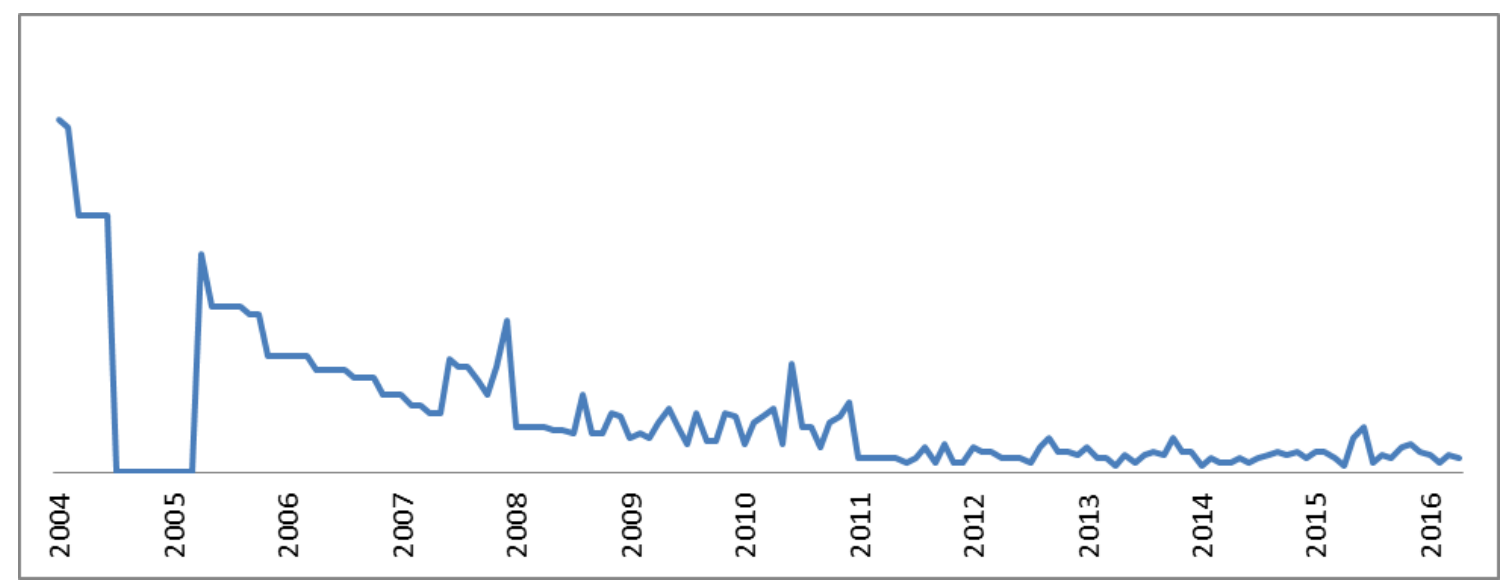

Figure 3. ‘Sustainable Consumption’ India Search Trend

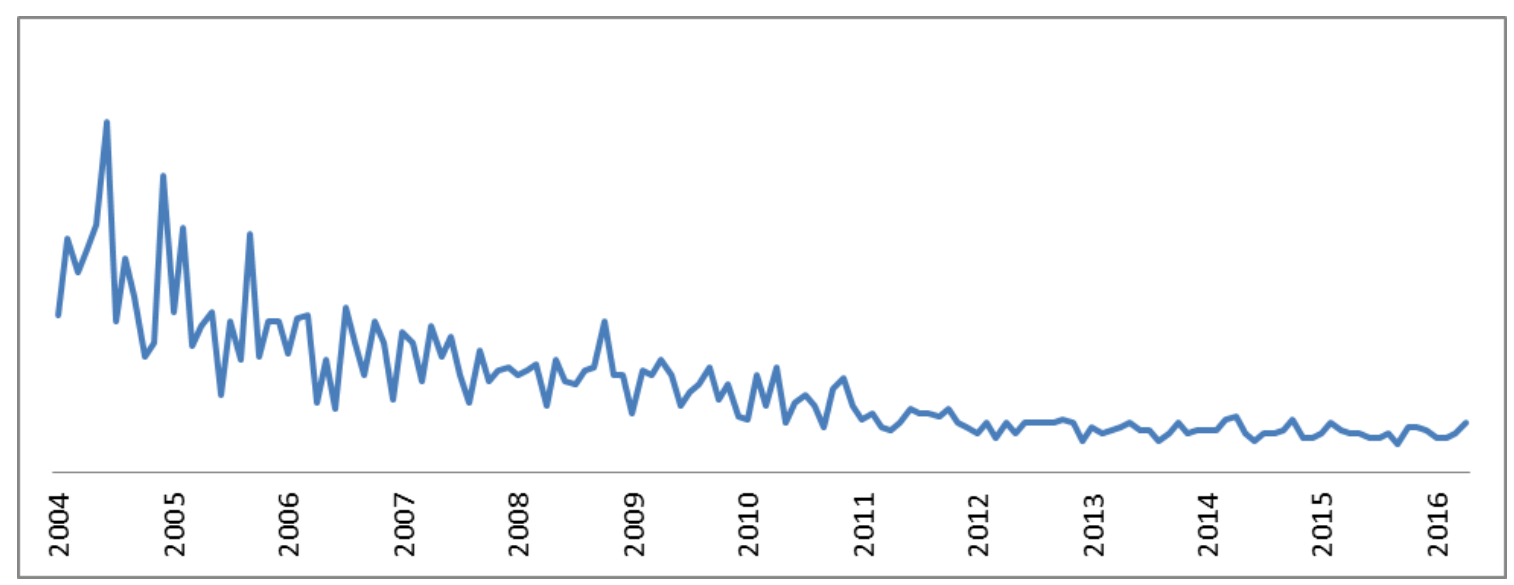

Figure 4. 'Electronic Appliances' India Search Trend

From an initial search of around 400 articles, filtration was done based on the abstract and conclusion to select 120 articles for further scrutiny. Finally, 38 articles (papers and reports) were considered for this review; most of these articles are related to TBP adoption around the world, and few are pertaining to studies conducted in developing countries like India and China. The most relevant journals for this study were found to be the Journal of Consumer Marketing, Sustainable Development, Business Strategy and The Environment, Journal of Consumer Behavior, International Journal of Retail and Distribution Management, Ecological Economics and International Journal of Research in Marketing. The review was focused on TBP adoption by consumers and not by industries. Articles referred for this review were only from well-known, internationally acclaimed publishers. Articles published by informal modes such as social networking and other websites were not included in the study.

\subsection{Analysis and Synthesis}

The relevant data was collected to find out the key ideas and methodologies used and were finally summarized to fit a comprehensive review article. The data related to the title, author, year, country, sector, models, and methodology were carefully analyzed, and opinions were produced in respective sections of this review paper. Three models on TBP adoption were discussed in this review paper, and inferences were drawn for future studies needed in the 
area of TBP adoption for climate proactivity, particularly in India.

\section{Literature Review}

With growing global attention towards environmental concerns during end years of the 20th century, it was also quite clear that technical as well as social improvements are the key approaches for providing environmental and social sustainability. Comprehensive research has been conducted in the past 25 years in the field of TBP adoption in different countries. This section summarizes the key determinants responsible for TBP adoption. The elements acknowledged by the research studies could be drivers and (or) barriers of TBP adoption based on the condition, period, and perspectives in which they are considered.

\subsection{Research Outcomes}

The literature survey suggests that the adoption of Technology-based Products is influenced by different variables such as product quality, price of the product, brand name, energy efficiency, credible product information, availability, consumer behavior, consumer knowledge \& awareness, peer pressure, and social status. A review by Faiers et al. (2007) classifies the various factors affecting TBP adoption. These factors are consumer choice, needs, social learning, buying process and product attributes (quality, cost and brand). Similarly, studies by Wheale and Hinton (2007), Biel and Dahlstrand (2005), and Sener and Hazer (2008) have identified different determinants that could influence the consumer behavior towards sustainable consumption. The identified determinants by these researchers are brand strength, culture, finance, habit, demographic characteristics, lack of information, lifestyle, personalities and ethical factors. The variables identified in the literature review are listed in Table 1 below.

Table 1. Variables for Technology-based Product Adoption by Consumers

\begin{tabular}{|c|c|}
\hline $\begin{array}{c}\text { Variables for the TBP } \\
\text { Adoption }\end{array}$ & Author \& Year \\
\hline $\begin{array}{l}\text { Product Quality/ } \\
\text { Product Performance }\end{array}$ & $\begin{array}{l}\text { Luchs et al., 2010; Ottman and Jacquelyn A., 1998; Sheth et al., 1991; Sen } \\
\text { and Bhattacharya, 2001; Webb et al., 2008; Sweeney et al., 1999; Baker et al., } \\
\text { 2002; Cronin et al., 2000; Sirohi et al., 1998; 1996; Keller, 1993; Matzler and } \\
\text { Hinterhuber, 1998; Forest L. Reinhardt , 1998; Tracy Tuten, 2013; Zeithaml et } \\
\text { al., }\end{array}$ \\
\hline Product Cost & $\begin{array}{l}\text { William Young et al., 2010; Sheth et al., 1991; Zou, Fang, and Zhao, 2003; } \\
\text { Morgan et al., 2004; Sweeney et al., 1999; Zeithaml, 1988; Lutzenhiser, 1994; } \\
\text { Hauge et al., 2012; Matzler and Hinterhuber, 1998; Tracy Tuten, 2013; } \\
\text { Williams and Dair, 2007; }\end{array}$ \\
\hline Product Brand & $\begin{array}{l}\text { Sheth et al., 1991; Moliner et al., 2007; Dodds et al., 1991; Dorsch et al., } \\
\text { 1998; Fletcher et al., 2000; Kumar et al., 1995; Hennig-Thurau et al., 2002; } \\
\text { Palmatier et al., 2006; \& Fournier, 1998; Garbarino and Johnson, 1999; }\end{array}$ \\
\hline
\end{tabular}




\begin{tabular}{|c|c|}
\hline Energy efficiency & $\begin{array}{l}\text { Williams and Dair, 2007; Lutzenhiser, 1994; Hauge et al., 2012; Hassett and } \\
\text { Metcalf 1993; Greene et al. 2006; Heinzle 2012; Heinzle and Wüstenhagen } \\
\text { 2012; Ölander and Thøgersen 2014; Sammer and Wüstenhagen 2006; Kotler, } \\
2011\end{array}$ \\
\hline $\begin{array}{l}\text { Credible Information, } \\
\text { Green Marketing/ } \\
\text { Eco-Claims }\end{array}$ & $\begin{array}{l}\text { Forest L. Reinhardt , 1998; Srivastava, 2007; Leonidou et al., 2013; Darnall } \\
\text { and Daniel, 2006; Miles and Kovin, 2000; Bellesi et al., 2005; Hultman et al., } \\
2011 \text { \& Leonidou and Katsikeas, 1996; Tracy Tuten, 2013; De Pelsmacker et } \\
\text { al., 2005; Luchs et al., 2010; William Young et al., 2010; Shafaat \& Sultan, } \\
\text { 2012; Sigal et al., } 2016\end{array}$ \\
\hline $\begin{array}{l}\text { Person's Behavior } \\
\text { (Ethical, Routine, Tradition, } \\
\text { Pro Environmental Behavior) }\end{array}$ & $\begin{array}{l}\text { Dobson, 2007; Luchs et al., 2010; Kilbourne and Beckmann, 1998; Nordlund } \\
\text { and Garvill, 2002; Bamberg, 2003; Krystallis et al. } 2011 \text { \& Martha \& Nalin, } \\
2009 \text {; Kilbourne and Pickett, 2008; Vermillion and Peart, } \\
2010\end{array}$ \\
\hline $\begin{array}{l}\text { Consumer } \\
\text { Knowledge/Awareness } \\
\text { (Technology, Performance, } \\
\text { Recycling, Non Toxic, etc...) }\end{array}$ & $\begin{array}{l}\text { Ottman et al., 2006; Schultz, 2001; Zimmer et al., } 1994 \text { \& Jody \& Annie, } \\
\text { 2014; Follows and Jobber } 2000 \& \text { Lee, 2009; Kurk and Eagan 2008; Tracy } \\
\text { Tuten, 2013; De Pelsmacker et al., 2005; Biel and Dahlstrand, } 2005\end{array}$ \\
\hline Availability & $\begin{array}{l}\text { Quelch and Harding, 1996; De Pelsmacker et al., 2005; Kotler, 2011; Quelch } \\
\text { and Harding, 1996; Simon, 1972); Stern, 2000, p. } 408\end{array}$ \\
\hline Peer Pressure & $\begin{array}{l}\text { Janssen and Jager, 2002; Menon et al., 2002; Buss \& Craik, 1983; Gannon \& } \\
\text { Ostrom, 1996; Dagher and Itani, 2012; Khan 2007; Janssen and Jager (2002); } \\
\text { Heinz and Jan, } 2009\end{array}$ \\
\hline Social Status & $\begin{array}{l}\text { Jerrell Richer, 1995; Grunert and Juhl 1995; Kim, Choi, and Rifon 2009; } \\
\text { Vermeir and Verbeke 2008; Schwartz, 1992; Lee, 2008: 582; Todd, 2004; } \\
\text { Baker and Ozaki (2008); Nyborg et al. 2006; Ajzen and Fishbein, } 1977\end{array}$ \\
\hline
\end{tabular}

The variables for TBP adoption was discussed in this section. The particular findings of the various studies on TBP are discussed in the following section.

\subsection{Major Findings from Literature}

While analyzing various research studies, the key findings were identified and summarized in a comprehensive way. The major findings of the literature study are presented in the below Table 2. 
Table 2. Findings on Technology-based Product Adoption by Consumers

\begin{tabular}{|c|c|c|}
\hline Author \& Year & Title & Major Findings \\
\hline $\begin{array}{l}\text { Sheth et al., } \\
1991\end{array}$ & $\begin{array}{l}\text { Why we buy what we buy: a } \\
\text { theory of consumption values. }\end{array}$ & $\begin{array}{l}\text { Non-green criteria such as brand name, cost, } \\
\text { reliability, look, services, routine habits and desires } \\
\text { reduces the consumers' green criteria while making a } \\
\text { purchase decision. }\end{array}$ \\
\hline $\begin{array}{l}\text { Sriram and } \\
\text { Forman, } 1993\end{array}$ & $\begin{array}{l}\text { The relative importance of } \\
\text { products' environmental } \\
\text { attributes: a cross-cultural } \\
\text { comparison }\end{array}$ & $\begin{array}{l}\text { - Consumers give less importance to the environmental } \\
\text { performance while purchasing high value products } \\
\text { compared to the low value products purchased } \\
\text { routinely. }\end{array}$ \\
\hline $\begin{array}{l}\text { Jerrell Richer, } \\
1995\end{array}$ & $\begin{array}{l}\text { "Green Giving: An Analysis } \\
\text { of Contributions to Major U.S. } \\
\text { Environmental Groups," }\end{array}$ & $\begin{array}{l}\text { - Rich countries and rich individuals spend a higher } \\
\text { fraction of their income on environmental goods. } \\
\text { - Wealthier people feel better social status by using } \\
\text { environmental goods and also able to bear the high } \\
\text { cost. }\end{array}$ \\
\hline $\begin{array}{l}\text { Quelch and } \\
\text { Harding, } 1996\end{array}$ & $\begin{array}{l}\text { Brands versus private labels: } \\
\text { fighting to win. }\end{array}$ & $\begin{array}{l}\text { - Consumers are more interested in buying green } \\
\text { products when they are available in plenty of verities } \\
\text { instead of one off availability. }\end{array}$ \\
\hline $\begin{array}{l}\text { Forest L. } \\
\text { Reinhardt, } \\
1998\end{array}$ & $\begin{array}{l}\text { Environmental Product } \\
\text { Differentiation: Implications for } \\
\text { Corporate Strategy }\end{array}$ & $\begin{array}{l}\text { - It is always difficult to technically differentiate } \\
\text { "environmentally preferable" products in an explicit } \\
\text { way. } \\
\text { - Companies have adopted various methods to } \\
\text { communicate the green features of the products. } \\
\text { Companies use Government-sponsored eco-labels, } \\
\text { third-party certification, and self-certification } \\
\text { initiatives to make their green claims. } \\
\text { - Credible Communication is a critical factor for } \\
\text { acceptance of products. }\end{array}$ \\
\hline $\begin{array}{l}\text { Ottman and } \\
\text { Jacquelyn A., } \\
1998\end{array}$ & $\begin{array}{l}\text { Green Marketing: Opportunity } \\
\text { for Innovation }\end{array}$ & $\begin{array}{l}\text { Environmentally sustainable products have performed } \\
\text { poorly compared to the non-green products. Poor } \\
\text { performance is a significant barrier to the consumers. } \\
\text { - It is observed that few consumers are associated } \\
\text { eco-friendly products having inferior performance. }\end{array}$ \\
\hline $\begin{array}{l}\text { De Pelsmacker } \\
\text { et al., } 2005\end{array}$ & $\begin{array}{l}\text { Do consumers care about } \\
\text { ethics? Willingness to pay for } \\
\text { fair-trade coffee. }\end{array}$ & $\begin{array}{l}\text { - Less availability, mistrust on the green labels and } \\
\text { absence of flawless information are the reasons for less } \\
\text { consumption of green products. }\end{array}$ \\
\hline $\begin{array}{l}\text { Biel and } \\
\text { Dahlstrand, } \\
2005\end{array}$ & $\begin{array}{l}\text { Values and habits: a } \\
\text { dual-process model }\end{array}$ & $\begin{array}{l}\text { Most of the time large household products are bought } \\
\text { during shifting of houses where there is paucity of time } \\
\text { to think of the green issues. } \\
\text { - Purchasing of large Technology-based Products need } \\
\text { more thoughtful approach than routine habits. }\end{array}$ \\
\hline
\end{tabular}




\begin{tabular}{|c|c|c|}
\hline Author \& Year & Title & Major Findings \\
\hline $\begin{array}{l}\text { Ottman et al., } \\
2006\end{array}$ & $\begin{array}{l}\text { Avoiding green marketing } \\
\text { myopia: ways to improve } \\
\text { consumer appeal for } \\
\text { environmentally preferable } \\
\text { products }\end{array}$ & $\begin{array}{l}\text { Awareness need to be increased among the consumers } \\
\text { on the green product claims of Technology-based } \\
\text { Products and their benefits to the consumer and to the } \\
\text { society. }\end{array}$ \\
\hline Dobson, 2007 & $\begin{array}{ll}\text { Environmental } & \text { citizenship: } \\
\text { towards } & \text { sustainable } \\
\text { development } & \end{array}$ & $\begin{array}{l}\text { - For creating behavioural change in the society } \\
\text { environmental beliefs need to be created through } \\
\text { education and awareness. This education must include } \\
\text { essential investigation, information analysis and } \\
\text { decision making skills. }\end{array}$ \\
\hline $\begin{array}{l}\text { Luchs et al., } \\
2010\end{array}$ & $\begin{array}{l}\text { The sustainability liability: } \\
\text { Potential negative effects of } \\
\text { ethicality on product preference }\end{array}$ & $\begin{array}{l}\text { - The positioning of a green product acceptance or } \\
\text { non-acceptance depends on the manufacturer's claims } \\
\text { on the product's efficiency and performance. }\end{array}$ \\
\hline $\begin{array}{l}\text { William Young } \\
\text { et al., } 2010\end{array}$ & $\begin{array}{l}\text { Sustainable Consumption: } \\
\text { Green Consumer } \\
\text { Behaviour when Purchasing } \\
\text { Products }\end{array}$ & $\begin{array}{l}\text { Even though green consumers are ready to pay higher } \\
\text { cost, lack of trust on green product claims is a } \\
\text { significant barrier for the acceptance of the products. } \\
\text { - Incentive from the Government on the premium cost } \\
\text { and more authentic green claims can help green } \\
\text { consumers to buy green products without much hassle. }\end{array}$ \\
\hline $\begin{array}{l}\text { Shafaat \& } \\
\text { Sultan, } 2012\end{array}$ & Green Marketing & $\begin{array}{l}\text { - One of the key challenges faced by green product } \\
\text { market is common standard to differentiate the green } \\
\text { products from the non-green products. The awareness } \\
\text { on green products is a key challenge for its acceptance }\end{array}$ \\
\hline $\begin{array}{l}\text { Tracy Tuten, } \\
2013\end{array}$ & $\begin{array}{l}\text { Promoting Sustainability by } \\
\text { Marketing Green Products to } \\
\text { Non-Adopters }\end{array}$ & $\begin{array}{l}\text { - The concerns about the global environmental issues } \\
\text { have increased very fast and the consequences are very } \\
\text { much visible. But the adoption of green products is } \\
\text { relatively very slow. } \\
\text { - The perception of high cost and low quality is } \\
\text { persisting with the consumers for a longer period. }\end{array}$ \\
\hline $\begin{array}{l}\text { Sigal et al., } \\
2016\end{array}$ & $\begin{array}{l}\text { Is Your Product Really Green? } \\
\text { A Content Analysis to Reassess } \\
\text { Green Advertising }\end{array}$ & $\begin{array}{l}\text { - Green-washing is very much present in the market } \\
\text { which deceives the average consumers due to lack of } \\
\text { awareness. Government need to intervene to deal with } \\
\text { the green-washing. }\end{array}$ \\
\hline
\end{tabular}

\subsection{Government Policies in India}

The Government of India (GOI) under the National Action Plan on Climate Change (NAPCC) has formulated the Bureau of Energy Efficiency (BEE), which regulates the energy star rating for electronic appliances (refrigerators and air conditioners etc...) in India. BEE is an autonomous body under the Central Electricity Rules, 2001. The star-rating system developed by the BEE helps consumers differentiate between the energy efficiency of appliances, with 
the appliance bearing fewer stars being less energy-efficient and vice versa.

Also, E-waste (Management and Handling) Rules, 2011 have 'Extended Producer Responsibility' (EPR), which puts the onus on the manufacturers to take responsibility for their products beyond manufacturing. The rule compels the manufacturers for environmentally sound management even after the end of life cycle of the product.

\section{Models on TBP Adoption}

There are a few models proposed by researchers on TBP adoption. These models are discussed below.

According to the framework "The Central Role of Private Investment Decisions" by Martha \& Nalin, (2009), the two main drivers of human emissions are behavior and capital stock. Behaviors such as switching off the lights when not in use, setting the temperature of air conditioners and cycling or walking the short distance travels are flexible, and can help reduce the emission by a simple change in behavior. Similarly, our capital investments such as purchasing a fuel-efficient car and acquiring an energy-efficient building are fixed in the short run, and lead to persistence in long term emissions.

Jody and Annie (2014) in their model suggest that firms should provide information about the product that is easy to understand for the average consumers. Their study suggests that manufacturers must not give technologically complicated information that is difficult to comprehend. The study states that high-level technical information hinders the adoption of Technology-based Products. As it is perceived that sustainable products and services are inferior (e.g., Luchs et al. 2010), information on quality, reliability and efficiency should be stressed while communicating the product information.

A research model by Tanushri and Arindam (2015) derives four major conclusions for Indian consumers on the purchasing of electronic appliances such as refrigerators and air conditioners. First, the influencing factors in decision-making on the purchase of energy-efficient star-rated appliances are primarily the brand name, look and feel, gifts and schemes, feedback provided by relatives and friends and their personal research work before the purchase. Second, the consumers are realizing the value of energy saving and clean environment as an outcome of using home appliances that are eco-friendly. Third, the consumers who believe in energy saving also consider environmental friendliness as an important factor while making a purchase decision. Fourth, the consumers give priority to star-rated appliances during the purchase of refrigerators and air conditioners in India.

\section{Discussion and Remarks}

Research reveals that individual consumptions contribute significantly to the Greenhouse Gas emission that is responsible for climate change. As discussed in the previous section, consumer behavior and capital stock are two primary reasons for human emissions. Only green product development and stricter environmental standards might not necessarily benefit the environment. Both low-tech and high-tech solutions are available for individuals, which will contribute towards lower human emissions. Little work is reported in the literature (for 
example; Heinz Welsch \& Jan Kuhling, 2009) about what motivates / demotivates consumers to adopt green products. There is a lack of guidance or framework that can help to promote green Technology-based Products amongst consumer groups.

This study on the consumers is based on the Technology-based Product adoption where there is medium range investment. The study does not include the low-cost consumer goods such as stationaries, eatables and cosmetics and high-cost investments such as procuring a vehicle or acquiring a house, which involves continuous GHG emissions throughout its lifetime. Specific studies can be conducted to ascertain the determinants for low and high capital investments. The consumer studies can be extended further to analyze the role of Governments towards the adoption of different products by the consumers, because apart from industrial GHG emissions, domestic GHG emissions also contribute significantly to climate change. As discussed in section 3.3, Government policies in India are not sufficient to help consumers adopt Technology-based Products. The Government must usher innovative, well-planned policies to encourage consumers to adopt green products. Most of the research studies on climate change are industry-oriented. This study suggests that equal emphasis needs to be given to the consumers and extensively focused research has to be carried out to enhance the consumer awareness to deal with the global climate problem.

\section{References}

Ajzen, I., \& Fishbein, M. (1977). Attitude-behavior relations: a theoretical analysis and review of empirical research. Psychological Bulletin, 84(5), 888-918. http://dx.doi.org/10.1037/0033-2909.84.5.888

Alex Shourmatoff, (2007). For a vivid description of the impact of our daily actions, see, "An Eco- System of One's Own". Vanity Fair.

Ansari, A., \& Riasi, A. (2016). An Investigation of Factors Affecting Brand Advertising Success and Effectiveness. International Business Research, 9(4), 20-30. http://dx.doi.org/10.5539/ibr.v9n4p20

Baker J, Ozaki R. (2008). Pro-environmental products: marketing influence on consumer purchase decision. Journal of Consumer Marketing, 25(5), 281-293. http://dx.doi.org/10.1108/07363760810890516

Baker, J., Parasuraman, A., Grewal, D., \& Voss, G. B. (2002). The influence of multiple store environment cues on perceived merchandise value and patronage intentions. Journal of Marketing, 66, 120-141. http://dx.doi.org/10.1509/jmkg.66.2.120.18470

Bamberg, S. (2003). How does environmental concern influence specific environmentally related behaviours? A new answer to an old question. Journal of Environmental Psychology, 23, 21-32. http://dx.doi.org/10.1016/S0272-4944(02)00078-6

Bellesi, Florencia, David Lehrer, \& Alon Tal (2005). Comparative Advantage: The Impact of ISO 14001 Environmental Certification on Exports. Environmental Science \& Technology, 39(7), 1943-53. http://dx.doi.org/10.1021/es0497983 
Biel A, Dahlstrand U. (2005). Values and habits: a dual-process model. In Environment, Information and Consumer Behavior, Krarup S, Russell CS (eds). Elgar: Cheltenham; 33-50.

Buss, D. M., \& Craik, K. H. (1983). The act frequency approach to personality. Psychological Review, 90(2), 105-126. http://dx.doi.org/10.1037/0033-295X.90.2.105

Cronin, J. J., Brady, M. K., \& Hult, G. T. M. (2000). Assessing the effects of quality, value, and customer satisfaction on consumer behavioral intentions in service environments. Journal of Retailing, 76, 193-218. http://dx.doi.org/10.1016/S0022-4359(00)00028-2

Dagher G, Itani O. (2012). The influence of environmental attitude, environmental concern and social influence on green purchasing behaviour. Review of Business Research 12(2), 104-111.

Darnall, Nicole \& Daniel Edwards Jr. (2006), "Predicting the Cost of Environmental Management System Adoption: The Role of Capabilities, Resources, and Ownership Structure," Strategic Management Journal, 27(2), 310-20. http://dx.doi.org/10.1002/smj.518

De Pelsmacker P, Driesen L, Rayp G. (2005). Do consumers care about ethics? Willingness to pay for fair-trade coffee. Journal of Consumer Affairs, 39(2), 363-385. DOI:. http://dx.doi.org/10.1111/j.1745-6606.2005.00019

Dobson A. (2007). Environmental citizenship: towards sustainable development. Sustainable Development, 15, 276-285. DOI: http://dx.doi.org/10.1002/sd.344

Dodds, W. B., Monroe, K. B., \& Grewal, D. (1991). Effects of price, brand, and store information on buyers' product evaluations. Journal of Marketing Research, 28, 307-319. http://dx.doi.org/10.2307/3172866

Dorsch, M. J., Swanson, S. R., \& Kelley, S. W. (1998). The role of relationship quality in the stratification of vendors as perceived by customers. Journal of the Academy of Marketing Science, 26,128-142. http://dx.doi.org/10.1177/0092070398262004

Faiers A, Cook M, Neame C. (2007). Towards a contemporary approach for understanding consumer behaviour in the context of domestic energy use. Energy Policy, 35, 4381-4390. http://dx.doi.org/10.1016/j.enpol.2007.01.003

Fletcher, G. J. O., Simpson, J. A., \& Thomas, G. (2000). Themeasurement of perceived relationship quality components. Personality and Social Psychology Bulletin, 26, 340-354. http://dx.doi.org/10.1177/0146167200265007

Follows, S. B., \& Jobber, D. (2000). Environmentally responsible purchase behaviour: A test of a consumer model. European Journal of Marketing, 34, 723-746. http://dx.doi.org/10.1108/03090560010322009

Forest L. Reinhardt (1998). Environmental Product Differentiation: Implications For Corporate Strategy. California Management Review, 40(4). http://dx.doi.org/10.2307/41165964

Fournier, S. (1998). Consumers and their brands: Developing relationship theory in consumer 
research. Journal of Consumer Research, 24, 343-373. http://dx.doi.org/10.1086/209515

Gannon, K. M., \& Ostrom, T. M. (1996). How meaning is given to rating scales: The effects of response language on category activation. Journal of Experimental Social Psychology, 32(4), 337-360. http://dx.doi.org/10.1006/jesp.1996.0016

Garbarino, E., \& Johnson, M. S. (1999). The different roles of satisfaction, trust, and commitment in customer relationships. Journal of Marketing, 63, 70-87. http://dx.doi.org/10.2307/1251946

Greene, D., Goeltz, R., Hopson, J., \& Tworek, E. (2006). Analysis of in-Use fuel economy shortfall by means of voluntarily reported fuel economy estimates. Transportation Research Record: Journal of the Transportation Research Board, 1983(-1), 99-105. http://dx.doi.org/10.3141/1983-14

Grunert, S. C., \& H. J. Juhl (1995). Values, Environmental Attitudes, and Buying of Organic Foods. Journal of Economic Psychology, 16, 39-62. http://dx.doi.org/10.1016/0167-4870(94)00034-8

Hassett, K. A., \& Metcalf, G. E. (1993). Energy conservation investment: Do consumers discount the future correctly? Energy Policy, 21(6), 710-716. http://dx.doi.org/10.1016/0301-4215(93)90294-P

Hauge, A.L., Thomsen, J., Löfström, E., (2012). How to get residents / owners in-housing cooperatives to agree on sustainable renovation. Energy Efficiency, http://dx.doi.org/10.1007/s12053-012-9175-5

Heinz Welsch \& Jan Kühling (2009). Determinants of pro-environmental consumption: The role of reference groups and routine behavior. Ecological Economics, 69(2009) 166-176. http://dx.doi.org/10.1016/j.ecolecon.2009.08.009

Heinzle, S. (2012). Disclosure of energy operating cost information: A silver bullet for overcoming the energyefficiency gap? Journal of Consumer Policy, 35(1), 43-64. http://dx.doi.org/10.1007/s10603-012-9189-6

Heinzle, S. L., \& Wüstenhagen, R. (2012). Dynamic adjustment of eco-labeling schemes and consumer choice - the revision of the EU energy label as a missed opportunity? Business Strategy and the Environment, 21(1), 60-70. http://dx.doi.org/10.1002/bse.722

Hennig-Thurau, T., Gwinner, K. P., \& Gremler, D. D. (2002). Understanding relationship marketing outcomes. Journal of Service Research, 4, 230-247. http://dx.doi.org/10.1177/1094670502004003006

Hultman, Magnus, Constantine S. Katsikeas, and Matthew J.Robson (2011). Export Promotion Strategy and Performance: The Role of International Experience. Journal of International Marketing, 19(4), 17-39. http://dx.doi.org/10.1509/jim.11.0022

Janssen, M. A., Jager, W., (2002). Stimulating diffusion of green products: co-evolution between firms and consumers. Journal of Evolutionary Economics, 12, 283-306. 
http://dx.doi.org/10.1007/s00191-002-0120-1

Jerrell Richer (1995). Green Giving: An Analysis of Contributions to Major U.S. Environmental Groups. Resources for the Future discussion paper \#95-39, Washington, D.C.

Jody L. Crosno \& Annie Peng Cui. (2014). A Multilevel Analysis of the Adoption of Sustainable Technology. Journal of Marketing Theory and Practice, 22(2), 209-224. http://dx.doi.org/10.2753/MTP1069-6679220213

Keller, Kevin Lane (1993). Conceptualizing, Measuring, and Managing Customer-Based Brand 'Equity. Journal of Marketing, 57(1), 1-22. http://dx.doi.org/10.2307/1252054

Kilbourne, W. E., \& Beckmann, S. C. (1998). Review and critical assessment of research on marketing and the environment. Journal of Marketing Management, 14, 513-532. http://dx.doi.org/10.1362/026725798784867716

Kilbourne, William, and Gregory Pickett (2008). How Materialism Affects Environmental Beliefs, Concern, and Environmentally Responsible Behavior. Journal of Business Research, 61(9), 885-893. http://dx.doi.org/10.1016/j.jbusres.2007.09.016

Kim, Y., S. M. Choi, \& N. Rifon (2009). A Cross-Cultural Study of Value Structure and Environmental Consumerism: The Case of Korean and United States Consumers. Korean Journal of Marketing, 10(4), 35-64.

Kotler P. (2011). Reinventing marketing to manage the environmental imperative. Journal of Marketing, 75(4), 132-135. http://dx.doi.org/10.1509/jmkg.75.4.132

Krystallis, A., Grunert, K., Verbeke, W., Perrea, T., \& Barcellos, M. (2011). How sustainable we want our food to be? Insights on the link between citizen and customer role in the EU and China. In Proceedings of the AMA Marketing \& Public Policy Conference. Washington.

KSG Working Paper Series No. RWP03-012 (2003). Carbon prices can be internalized, either through the imposition of a carbon tax or by setting emissions limits and use markets to allocate across users (cap and trade). The uncertainties in the mechanisms through which GHG effluents affect climate, as well as the uneven distribution of impacts, makes designing and implementing a global climate mitigation scheme extremely difficult. For a critical analysis of climate change policy architectures, see Joseph Aldy, Scott Barret, and Robert Stavins, "Thirteen plus One: A Comparison of Global Climate Policy Architectures".

Kumar, N., Scheer, L. K., \& Steenkamp, J. B. (1995). The effects of supplier fairness on vulnerable resellers. Journal of Marketing Research, 32, 54-65. http://dx.doi.org/10.2307/3152110

Kurk, F., \& Eagan, P. (2008). The value of adding design-for-the-environment to pollution prevention assistance options. Journal of Cleaner Production, 16(6), 722-726. http://dx.doi.org/10.1016/j.jclepro.2007.02.022

Lee K. (2008). Opportunities for green marketing: young consumer. Marketing Intelligence and planning, 26(6), 573-586. http://dx.doi.org/10.1108/02634500810902839 
Lee, K. (2009). Gender difference in Hong Kong adolescent consumers' green purchasing $\begin{array}{llll}\text { behaviour. Journal of } \text { Consumer } & \text { Marketing, }\end{array}$ http://dx.doi.org/10.1108/07363760910940456

Leonidou and Constantine S. Katsikeas (1996). The Export Development Process: An Integrative Review of Empirical Models. Journal of International Business Studies, 27(3), 517-51. http://dx.doi.org/10.1057/palgrave.jibs.8490846

Leonidou, Constantinos N, Constantine S. Katsikeas, \& Neil A. Morgan (2013). Greening the Marketing Mix: Do Firms Do It and Does It Pay Off? Journal of the Academy of Marketing Science, 41(2), 151-70, http://dx.doi.org/10.1007/s11747-012-0317-2

Luchs, M. G., Naylor, R. W., Irwin, J. R. \& Raghunathan, R. (2010). The sustainability liability: Potential negative effects of ethicality on product preference. Journal of Marketing, 74(September): 18-31. http://dx.doi.org/10.1509/jmkg.74.5.18

Lutzenhiser, L. (1994). Innovation and organizational networks barriers to energy efficiency in the US housing industry. Energy Policy, 22(10), 867-876. http://dx.doi.org/10.1016/0301-4215(94)90146-5

Martha Amram \& Nalin Kulatilaka, Winter (2009). California Management Review, 51(2). Cmr.Berkeley.Edu

Matthew E. Kahn. (2007). Do greens drive Hummers or hybrids? Environmental ideology as a determinant of consumer choice. Journal of Environmental Economics and Management, 54, 129-145. http://dx.doi.org/10.1016/j.jeem.2007.05.001

Matzler, K and H Hinterhuber (1998). How to make product development projects more successful by integrating Kano's model of customer satisfaction into quality function deployment. Technovation, 18(1), 25-38. http://dx.doi.org/10.1016/S0166-4972(97)00072-2

Menon, G., Block, L. G., \& Ramanathan, S. (2002). We're at as much risk as we are led to believe: Effects of message cues on judgments of health risk. Journal of Consumer Research, 28(4), 533-549. http://dx.doi.org/10.1086/338203

Miles, Morgan P., \& Jeffrey G, Covin. (2000). Environmental Marketing: A Source of Reputational, Competitive, and Financial Advantage. Journal of Business Ethics, 23(3), 299-311. http://dx.doi.org/10.1023/A:1006214509281

Moliner, M. A., Sanchez, R. M., Rodriguez, J., \& Callarisa, L. (2007). Perceived relationship quality and post-purchase perceived value. European Journal of Marketing, 41, 1392-1422. http://dx.doi.org/10.1108/03090560710821233

Morgan, Neil A., Anna Kaleka, and Constantine S. Katsikeas (2004). Antecedents of Export Venture Performance: A Theoretical Model and Empirical Assessment. Journal of Marketing, 68(January), 90-108. http://dx.doi.org/10.1509/jmkg.68.1.90.24028

Nordlund, A. M., \& Garvill, J. (2002). Value structures behind pro-environmental behavior. Enviroment and Behavior, 34(6), 740-756. http://dx.doi.org/10.1177/001391602237244 


\section{Macrothink}

Environmental Management and Sustainable Development

ISSN 2164-7682

2016, Vol. 5, No. 2

Nyborg K, Howarth R, Brekke K. (2006). Green consumers and public policy: on socially contingent moral motivation. Resource and Energy Economics, 28(4), 351-366. http://dx.doi.org/10.1016/j.reseneeco.2006.03.001

Ölander, F., \& Thøgersen, J. (2014). Informing versus nudging in environmental policy. Journal of Consumer Policy, 37(3), 341-356. Sallee, J. Rational inattention. http://dx.doi.org/10.1007/s10603-014-9256-2

Ottman JA, Stafford ER, Hartman CL. (2006). Avoiding green marketing myopia: ways to improve consumer appeal for environmentally preferable products. Environment: Science and Policy for Sustainable Development, 48(5), 22-36. DOI: http://dx.doi.org/10.3200/ENVT.48.5.22-36

Ottman, Jacquelyn A. (1998), Green Marketing: Opportunity for Innovation, New York: McGraw-Hill.

Palmatier, R. W., Dant, R. P., Grewal, D., \& Evans, K. R. (2006). Factors influencing the effectiveness of relationship marketing: A meta-analysis. Journal of Marketing, 70, 136-153. http://dx.doi.org/10.1509/jmkg.70.4.136

Quelch JA, Harding D. (1996). Brands versus private labels: fi ghting to win. Harvard Business Review 74(1), 99-109.

Riasi, A., \& Amiri Aghdaie, S. F. (2013). Effects of a Hypothetical Iranian Accession to the World Trade Organization on Iran's Flower Industry. Consilience: The Journal of Sustainable Development, 10(1), 99-110. http://dx.doi.org/10.7916/D8HQ3ZK8

Sammer, K., \& Wüstenhagen, R. (2006). The influence of eco-labelling on consumer behaviour - Results of a discrete choice analysis for washing machines. Business Strategy and the Environment, 15(3), 185-199. http://dx.doi.org/10.1002/bse.522

Schultz, P. W. (2001). The structure of environmental concern: Concern for self, other people and the biosphere. Journal of Environmental Psychology, 21, 327-339. http://dx.doi.org/10.1006/jevp.2001.0227

Schwartz, S. H. (1992). Universals in the Content and Structure of Values: Theoretical Advances and Empirical Tests in 20 Countries. Advances in Experimental Social Psychology, 25, 1-65. http://dx.doi.org/10.1016/S0065-2601(08)60281-6

Sen, S., \& Bhattacharya, C. B. (2001). Does doing good always lead to doing better? Consumer reactions to corporate social responsibility. Journal of Marketing Research, 38, 225-243. http://dx.doi.org/10.1509/jmkr.38.2.225.18838

Sener A, Hazer O. (2008). Values and sustainable consumption behaviour of women: a Turkish sample. Sustainable Development, 16(5), 291-300. http://dx.doi.org/10.1002/sd.329

Shafaat, A.; Sultan, A. (2012). Green Marketing. Excel International Journal of Multidisciplinary Management Studies. 2(5).

Sheth JN, Newman BI, Gross BL. (1991). Why we buy what we buy: a theory of 
consumption values. Journal of Business Research, 22, 159-170. http://dx.doi.org/10.1016/0148-2963(91)90050-8

Sigal Segev, Juliana Fernandes \& Cheng Hong (2016). Is Your Product Really Green? A Content Analysis to Reassess Green Advertising; Journal of Advertising, 45(1), 85-93. http://dx.doi.org/10.1080/00913367.2015.1083918

Simon, H. A. (1972). Theories of bounded rationality. In: McGuire, C.B., Radner, R. (Eds.), Decision and Organization. North Holland, Amsterdam.

Sirohi, N., McLaughlin, E. W., \& Wittink, D. R. (1998). A model of consumer perceptions and store loyalty intentions for a supermarket retailer. Journal of Retailing, 74, 223-245. http://dx.doi.org/10.1016/S0022-4359(99)80094-3

Sriram V, Forman A. M. (1993). The relative importance of products' environmental attributes: a cross-cultural comparison. International Marketing Review, 10(3), 51-70. http://dx.doi.org/10.1108/02651339310040670

Srivastava S. K. (2007). Green Supply-Chain Management: A State-of-the-Art Literature Review. International Journal of Management Reviews, 9(1), 53-80. http://dx.doi.org/10.1111/j.1468-2370.2007.00202.x

Stern, P. C. (2000). Toward a coherent theory of environmentally significant behavior. Journal of Social Issues, 56(3), 407-24. http://dx.doi.org/10.1111/0022-4537.00175

Sweeney, J. C., Soutar, G. N., \& Johnson, L. W. (1999). The role of perceived risk in the quality-value relationship: A study in a retail environment. Journal of Retailing, 75, 77-105. http://dx.doi.org/10.1016/S0022-4359(99)80005-0

Tanushri Banerjee, Arindam Banerjee (2015). Evaluating the Purchase Process of Household Appliances Accounting for Consumers' Attitudes towards Eco-Friendly and Sustainable Consumption Behavior. Indian Institute of Management, Ahemadabd, W. P. No. 2015-06-01.

Todd A. (2004). The aesthetic turn in green marketing: environmental consumer ethics of natural personal care products. Ethics and the Environment, 9(2), 86-102. http://dx.doi.org/10.2979/ETE.2004.9.2.86

Tracy Tuten, (2013). Promoting Sustainability by Marketing Green Products to Non-Adopters; Gestion 2000, 2013/2 (Volume 30), 93-102.

Vermeir, I., \& W. Verbeke (2008). Sustainable Food Consumption among Young Adults in Belgium: Theory of Planned Behavior and Role of Confidence and Values. Ecological Economics, 64, 542-553. http://dx.doi.org/10.1016/j.ecolecon.2007.03.007

Vermillion L, Peart J. (2010). Green marketing: making sense of the situation. Proceeding of the Academy of Marketing Studies, 15(1), 68-72. Allied Academies International Conference.

Webb, D., Mohr, L. A., \& Harris, K. E. (2008). A re-examination of socially responsible consumption and its measurement. Journal of Business Research, 61, 91-98. http://dx.doi.org/10.1016/j.jbusres.2007.05.007 
Wheale P, Hinton D. (2007). Ethical consumers in search of markets. Business Strategy and the Environment, 16, 302-315. DOI: http://dx.doi.org/10.1002/bse.484

William Young, Kumju Hwang, Seonaidh McDonald and Caroline J. Oates (2010). Sustainable Consumption: Green Consumer Behaviour when Purchasing Products. Sustainable Development. Sust. Dev. 18, 20-31.

Williams, K., Dair, C. (2007). What is stopping sustainable building in England? Barriers experienced by stakeholders in delivering sustainable developments. Sustainable Developments, 15(3), 135-147. http://dx.doi.org/10.1002/sd.308

Zeithaml, V. A. (1988). Consumer perceptions of price, quality and value: A means-end model and synthesis of evidence. Journal of Marketing, 52, 2-22. http://dx.doi.org/10.2307/1251446

Zeithaml, V. A., Berry, L. L., \& Parasuraman, A. (1996). The behavioral consequences of service quality. Journal of Marketing, 60, 31-46. http://dx.doi.org/10.2307/1251929

Zimmer, M. R., Stafford, T. F., \& Stafford, M. R. (1994). Green issues: Dimensions of environmental concern. Journal of Business Research, 30, 63-74. http://dx.doi.org/10.1016/0148-2963(94)90069-8

Zou, Shaoming, Eric Fang, \& Shuming Zhao (2003). The Effect of Export Marketing Capabilities on Export Performance: An Investigation of Chinese Firms. Journal of International Marketing, 11(4), 32-55. http://dx.doi.org/10.1509/jimk.11.4.32.20145

\section{Copyright Disclaimer}

Copyright for this article is retained by the author(s), with first publication rights granted to the journal.

This is an open-access article distributed under the terms and conditions of the Creative Commons Attribution license (http://creativecommons.org/licenses/by/3.0/) 